\title{
REVIEW
}

\section{Unproven Therapies for Diabetes and Their Implications}

\author{
Jothydev Kesavadev • Banshi Saboo - Shaukat Sadikot - Ashok Kumar Das • \\ Shashank Joshi · Rajeev Chawla · Hemant Thacker · Arun Shankar · \\ Lakshmy Ramachandran · Sanjay Kalra
}

Received: September 22, 2016 / Published online: November 18, 2016

(C) The Author(s) 2016. This article is published with open access at Springerlink.com

\begin{abstract}
Diabetes is a chronic disease and is one of the leading causes of morbidity and mortality worldwide. Being an ancient disease, many individuals follow complementary and alternative medicinal (CAM) therapies for either the cure or prevention of the disease. The popularity of these practices among the general public is in no way a testimony to their safety and efficacy. Due to the possibility of undesirable interactions with conventional medicines, it is
\end{abstract}

Enhanced content To view enhanced content for this article go to http://www.medengine.com/Redeem/ 5517F0607657C47F.

J. Kesavadev ( $\square)$ · A. Shankar · L. Ramachandran Jothydev's Diabetes Research Centre, Trivandrum, Kerala, India

e-mail: jothydev@gmail.com

B. Saboo

Dia Care and Hormone Clinic, Ahmedabad, Gujarat, India

\section{S. Sadikot}

Department of Endocrinology/Diabetology, Jaslok

Hospital and Research Centre, Mumbai, India

\section{A. K. Das}

Department of Endocrinology, Jawaharlal Institute of Postgraduate Medical Education and Research, Puducherry, India imperative that patients are asked about CAM use during patient assessment. Patient- and physician-targeted awareness programs on various aspects of CAM use must be initiated to create a better understanding of evidence-based use of these practices. In addition, there should be guidelines in place based on clinical trial outcomes, and stricter regulations need to be enforced on CAM practices to ensure their safety and effectiveness.

Keywords: Ayurveda; CAM; Complementary and alternative medicine; Diabetes; Herbal medicine; Supplements; TM; Traditional medicine

S. Joshi

Department of Diabetology, Lilavati Hospital and Research Centre, Mumbai, India

R. Chawla

North Delhi Diabetes Centre, New Delhi, India

\section{H. Thacker}

Department of Endocrinology, Bhatia Hospital, Mumbai, India

S. Kalra

Department of Endocrinology, Bharati Hospital, Karnal, Haryana, India 


\section{INTRODUCTION}

\section{Worldwide Prevalence of Diabetes}

The World Health Organization (WHO) defines diabetes as a serious chronic disease that manifests either when the pancreas does not produce enough insulin (a hormone that regulates blood glucose) or when the body cannot effectively use the insulin it produces [1]. Diabetes, if not managed, can damage many organs of the body such as the kidneys, heart, eyes, blood vessels, and nerves. As per International Diabetes Federation (IDF) statistics, about 415 million adults were afflicted with the disease in 2015, and this number is estimated to be 642 million by the year 2040. It also estimated that more than half a million children aged 14 and under are affected with type 1 diabetes mellitus (T1DM) [2]. Diabetes accounts for one death every $6 \mathrm{~s}$, and the number of deaths caused by diabetes is 5 million, a figure much higher than those caused by HIV (1.5 million), tuberculosis (1.5 million), and malaria (0.6 million) combined $[2,3]$.

With advances in modern medicine, a dramatic improvement in life expectancy was achieved after 1940. As per the WHO, the average life span of a child born in 2015 is predicted to be 71.4 years, whereas earlier estimates of global life expectancy were 30.9 years in 1900, 46.7 in 1940, and 61.13 in 1980. [4, 5]. Diabetes being a disease that accounts for a huge economic burden as well as physical and mental disability, all patients should have the privilege of receiving effective therapies with the fewest adverse effects. Special precautions must be undertaken while managing elderly patients because of the interplay among different factors such as age, genetics, lifestyle, and physiological conditions that are known to aggravate the disease. In an earlier review, we discussed in detail the pathophysiology of diabetes in the elderly and the necessity for individualized care and proven therapies to prevent disability in advancing age [6].

\section{History of Diabetes}

Diabetes is an ancient disease that was known to physicians more than 3500 years ago. The Ebers Papyrus, considered the greatest Egyptian medical document, describes diabetes as a condition of "too great emptying of the urine" $[7,8]$. Indian physicians around the same time observed that the urine of individuals with diabetes attracted ants and flies. They referred to it as "madhumeha" or "honey urine" and also noted that these patients suffered from extreme thirst and foul breath (likely due to ketosis). Conditions such as polyuria and glycosuria were also documented by physicians of that time [8-10]. The first ever scientific remedy, the discovery of insulin, was developed in 1922, winning its discoverers the Nobel Prize in 1923 [11], whereas the first ever oral scientific remedy, sulphonylurea, was not available until the 1950s. Hence the physicians, prior to the discovery of these modern medicines, had no other choice than to use locally available indigenous medicines. In the current scenario, depending on the type of diabetes and its etiology, patients may be treated with either an oral drug or injectable or a combination of both. In T1DM with absolute insulin deficiency, insulin pump therapy or multiple daily insulin injections are the only therapeutic modalities, in the absence of which subjects are likely to die.

\section{Diabetes-Related Complications}

Diabetes burdens different organ systems, and therefore subjects with diabetes have a greater risk of developing serious health complications. Acute complications such as diabetic 
ketoacidosis (resulting from insulin deficiency) and coma (resulting from hypoglycemia) often result in the death of the individual. Chronic elevation of blood glucose levels presents with vascular complications, either microvascular (neuropathy, nephropathy, retinopathy) or macrovascular (cardiovascular disease, stroke, peripheral vascular disease) in nature. Peripheral vascular disease often results in hard to heal bruises or injuries and gangrene, which may finally require amputations $[12,13]$. Dementia [14], depression [15], and sexual dysfunction [16, 17] have also often been found to be associated with diabetes.

\section{CAM Therapy and Popularity}

Many patients resort to complementary and alternative medicinal (CAM) practices at least once during their lifetime. 'Complementary' therapies are those that are used together with conventional treatment, whereas 'alternative' therapies are used in place of conventional treatment. The National Center for Complementary and Alternative Medicine (NCCAM), now renamed the National Center for Complementary and Integrative Health (NCCIH), is a subsidiary of the National Institutes of Health (NIH), USA, and refers to CAM as those healthcare approaches developed outside of the realm of conventional medicine. Complementary and alternative health approaches fall into one of two subgroups, viz., natural products and mind and body practices. Natural products (widely available and often sold as dietary supplements) consist of herbs (or botanicals), vitamins and minerals, and probiotics. Mind and body practices include a variety of procedures or techniques administered or taught by a trained practitioner or teacher (e.g., yoga, chiropractic and osteopathic manipulation, meditation, massage therapy, acupuncture, relaxation techniques, tai chi, etc.) [18].

The 2012 National Health Interview Survey revealed that about $33 \%$ of adults used complementary approaches, and natural products were found to be favored by $17 \%$ of adults and about $5 \%$ of children. In spite of having a comprehensive health insurance program, 59 million Americans have willingly spent a total of about 30 billion dollars on complementary health approaches $[19,20]$. Another study from Israel reported that almost every fourth patient with diabetes uses CAM [21]. Dissatisfaction arising from conventional therapies, at times, and higher treatment expenses, concern about the side effects of drugs, desire to have a grip on the course of the disease, and a notion that CAM therapies are compatible with patient values and beliefs [22-25] are some of the reasons why many choose CAM over conventional therapies. Considering this widespread popularity of various CAM practices, in this review we have made an effort to recapitulate their pros and cons pertaining to diabetes treatment.

\section{Compliance with Ethics Guidelines}

This article is based on previously conducted studies and does not involve any new studies of human or animal subjects performed by any of the authors.

\section{IMPLICATIONS OF CAM THERAPY FOR DIABETES TREATMENT}

\section{Frequently Used CAM Therapies for Diabetes}

Individuals with diabetes, cancer, and hypertension are found to be the predominant followers of CAM as compared to their healthy 
counterparts [26]. Individuals with diabetes tend to use CAM therapies mostly to complement conventional therapy and resort to nutritional advice or lifestyle diets, herbal remedies, massage therapy, spiritual healing, and meditation training $[26,27]$. Of the CAM therapies, those most popularly used and studied for diabetes treatment are herbs, dietary supplements, and mind-body medicine [28]. This is not surprising as many of them are widely available and inexpensive and are inherent in peoples' cultures and ancestral beliefs. An investigation using ethnographic methods was carried out on an urban population of Kerala to understand the usage of complementary therapies in managing type 2 diabetes mellitus (T2DM). The study pointed out that patients' perceptions of a disease and its management are largely based on their cultural background and environmental resources. Many of them frequently use Ayurvedic and traditional herbal medicines as supplements to conventional therapy [29]. An overview of natural products generally used for diabetes management is depicted in Table 1 (herbs) and Table 2 (dietary supplements).

\section{Impact of CAM Therapies in Diabetes Treatment Outcome}

The American Diabetes Association's Standards of Medical Care do not support the use of vitamin, mineral, or herbal supplements for diabetes management because of the lack of sufficient evidence [30]. Several systematic reviews have been published that assess the impact and efficacy of various CAM therapies on preventing and treating diabetes. Recently, the effect of Ayurveda on treating diabetes mellitus was studied by Sridharan et al., and the effect of Chinese herbal medicines on impaired glucose tolerance or impaired fasting blood glucose was assessed by Grant et al. Both of these reviews pointed out the benefits of following these traditional systems of medicine in treating diabetes or pre-diabetic conditions. The authors, however, stop short of recommending such practices, citing the biased nature of certain studies and lack of sufficient evidence [31, 32].

The popularity of these practices generally stems from patient's expectations of their efficacy [33] as well as being associated with advanced stages of the disease [34]. Some investigations into the psycho-social impacts of CAM practices have tried to evaluate the expectations and perceptions regarding their efficacy. In a study that included cancer patients, for many their expectations of positive CAM effects were not met [34]. In a survey conducted among participants in the SEARCH for Diabetes in Youth, patients who followed a 'CAM diet' reported a better quality of life (QOL), whereas supplement use and stress reduction activities resulted in decreased QOL. Besides, children who did not follow any CAM practices experienced fewer treatment barriers [35]. A similar trend was also reported by another study, where higher CAM use in fact correlated with a decreased quality of life in people with T2DM and/or cardiovascular disease. This was attributed to the negative effects of using multiple therapies because some of them could in fact interfere with conventional care [36].

CAM users were also found to show decreased adherence to prescribed medications. They become both logistically and psychologically burdened and may need to discontinue part or all of their prescribed diabetes medications to be able to continue using CAM [37]. CAM therapies, depending on the amount or type, can help or harm patients and often cause adverse responses, which 
Table 1 Commonly used herbs to treat diabetes

\begin{tabular}{|c|c|c|c|c|}
\hline Name & Active constituents & $\begin{array}{l}\text { Beneficial effects/ } \\
\text { hypothesized mechanism } \\
\text { of action }\end{array}$ & $\begin{array}{l}\text { Side effects/drug } \\
\text { interactions and } \\
\text { contradictions }\end{array}$ & References \\
\hline $\begin{array}{l}\text { Bitter melon } \\
\text { (Momordica } \\
\text { charantia) }\end{array}$ & $\begin{array}{l}\text { Momordin, charantin, } \\
\text { polypeptide } \mathrm{P} \text {, vicine }\end{array}$ & $\begin{array}{l}\text { Hypoglycemic action, } \\
\text { insulin mimetic, } \\
\text { enhances glucose uptake } \\
\text { by tissues, inhibition of } \\
\text { glucose producing } \\
\text { enzymes, enhances } \\
\text { glucose oxidation } \\
\text { (G6PDH pathway) }\end{array}$ & $\begin{array}{l}\text { Gastrointestinal } \\
\text { discomfort, hypoglycemic } \\
\text { coma, favism, hemolytic } \\
\text { anemia in persons with } \\
\text { G-6PDH deficiency, } \\
\text { abortifacient activity of } \alpha \\
\text { and } \beta \text { momorcharin, } \\
\text { hypoglycemia when used } \\
\text { with sulfonylureas }\end{array}$ & {$[28,117]$} \\
\hline $\begin{array}{l}\text { Fenugreek } \\
\text { (Trigonella } \\
\text { foenum- } \\
\text { graecum) }\end{array}$ & $\begin{array}{l}\text { Saponins, glycosides } \\
\text { Seeds contain: alkaloids, } \\
\text { 4-hydroxyisoleucine, } \\
\text { fenugreekine }\end{array}$ & $\begin{array}{l}\text { Insulin secretagog, } \\
\text { hypoglycemic activity, } \\
\text { lipid-lowering effects, } \\
\text { increase HDL } \\
\text { cholesterol, Slows } \\
\text { carbohydrate absorption } \\
\text { and delays gastric } \\
\text { emptying, inhibits } \\
\text { glucose transport, } \\
\text { increases insulin } \\
\text { receptors, improves } \\
\text { utilization of peripheral } \\
\text { glucose }\end{array}$ & $\begin{array}{l}\text { Diarrhea, gas, uterine } \\
\text { contractions, allergic } \\
\text { reactions, drug } \\
\text { interaction with } \\
\text { hypoglycemic agents, } \\
\text { anticoagulant drugs, } \\
\text { MAO inhibitors, } \\
\text { contraindicated in } \\
\text { pregnancy }\end{array}$ & {$[27,117]$} \\
\hline $\begin{array}{l}\text { Panex ginseng, } \\
P . \\
\text { quiquefolius } \\
\text { (Ginseng) }\end{array}$ & Ginsenosides & $\begin{array}{l}\text { Insulin mimetic, } \\
\text { hypoglycemic action, } \\
\text { enhances } \\
\text { psycho-physiological } \\
\text { performance, stimulates } \\
\text { immune system, may } \\
\text { decrease carbohydrate } \\
\text { absorption in portal } \\
\text { circulation, may increase } \\
\text { glucose transport and } \\
\text { uptake, may modulate } \\
\text { insulin secretion, alters } \\
\text { hepatic glucose } \\
\text { metabolism }\end{array}$ & $\begin{array}{l}\text { Estrogenic effect with } \\
\text { breast tenderness, } \\
\text { amenorrhea, vaginal } \\
\text { bleeding and impotence, } \\
\text { hypertension, insomnia, } \\
\text { interacts with } \\
\text { anticoagulant and } \\
\text { antiplatelet medications; } \\
\text { hypoglycemic agents; } \\
\text { corticosteroids; oral } \\
\text { contraceptives; digoxin; } \\
\text { MAO inhibitors and } \\
\text { tricyclic antidepressants; } \\
\text { diuretics }\end{array}$ & {$[27,28,118]$} \\
\hline
\end{tabular}


Table 1 continued

\begin{tabular}{|c|c|c|c|c|}
\hline Name & Active constituents & $\begin{array}{l}\text { Beneficial effects/ } \\
\text { hypothesized mechanism } \\
\text { of action }\end{array}$ & $\begin{array}{l}\text { Side effects/drug } \\
\text { interactions and } \\
\text { contradictions }\end{array}$ & References \\
\hline $\begin{array}{l}\text { Ginkgo } \\
\text { (Ginkgo } \\
\text { biloba) }\end{array}$ & $\begin{array}{l}\text { Flavonoids } \\
\text { (ginkgo-flavone } \\
\text { glycosides), terpenoids } \\
\text { (ginkgolides and } \\
\text { bilobalides) }\end{array}$ & $\begin{array}{l}\text { Inhibit the } \\
\text { platelet-activating factor, } \\
\text { useful in cerebrovascular } \\
\text { insufficiency and } \\
\text { peripheral vascular } \\
\text { disease, antioxidant, } \\
\text { neuroprotective }\end{array}$ & $\begin{array}{l}\text { Transient headaches, cross } \\
\text { allergenicity with poison } \\
\text { ivy, interacts with } \\
\text { anticoagulants, SSRI, } \\
\text { MAO inhibitors }\end{array}$ & {$[27,52,119]$} \\
\hline Aloe vera & Glucomannan & $\begin{array}{l}\text { Fiber may promote glucose } \\
\text { uptake, pharmacokinetic } \\
\text { interaction (CYP3A4), } \\
\text { pharmacodynamic } \\
\text { interaction } \\
\text { (enhancement in adipose } \\
\text { tissue insulin signaling } \\
\text { pathway) }\end{array}$ & $\begin{array}{l}\text { Abdominal pain, laxative } \\
\text { component induces } \\
\text { diarrhea, additive } \\
\text { hypoglycemia if } \\
\text { combined with } \\
\text { secretagogs, drug } \\
\text { interactions with } \\
\text { sevoflurane, pioglitazone, } \\
\text { repaglinide }\end{array}$ & {$[28,52,117,120]$} \\
\hline $\begin{array}{c}\text { Cinnamomum } \\
\text { zeylanicum }\end{array}$ & $\begin{array}{l}\text { Compound similar to } \\
\text { procyanidin type-A } \\
\text { polymers, coumarins }\end{array}$ & $\begin{array}{l}\text { Increases insulin sensitivity } \\
\text { by increasing PPAR } \\
\text { (alpha and gamma) } \\
\text { expression, increases } \\
\text { cellular glucose entry by } \\
\text { enhanced insulin } \\
\text { receptor phosphorylation } \\
\text { and translocation of } \\
\text { GLUT4 glucose } \\
\text { transporter to the plasma } \\
\text { membrane, promotes } \\
\text { glycogen synthesis }\end{array}$ & $\begin{array}{l}\text { Skin irritations if used } \\
\text { topically, interacts with } \\
\text { secretagogs and cause } \\
\text { hypoglycemia, coumarins } \\
\text { possess anticoagulant, } \\
\text { carcinogenic, and } \\
\text { hepatotoxic properties }\end{array}$ & {$[117,121]$} \\
\hline $\begin{array}{r}\text { Gymnema } \\
\text { sylvestre }\end{array}$ & $\begin{array}{l}\text { Gymnemosides, } \\
\text { saponins, stigmasterol, } \\
\text { and amino acid } \\
\text { derivatives (e.g., } \\
\text { betaine, choline, and } \\
\text { trimethylamine) }\end{array}$ & $\begin{array}{l}\text { Insulin secretagog, increases } \\
\text { glucose uptake } \\
\text { promoting enzymes, } \\
\text { stimulates and increase } \\
\text { beta cell number }\end{array}$ & $\begin{array}{l}\text { May cause hypoglycemia } \\
\text { when combined with } \\
\text { secretagogs }\end{array}$ & {$[28,117]$} \\
\hline
\end{tabular}


Table 1 continued

\begin{tabular}{|c|c|c|c|c|}
\hline Name & Active constituents & $\begin{array}{l}\text { Beneficial effects/ } \\
\text { hypothesized mechanism } \\
\text { of action }\end{array}$ & $\begin{array}{l}\text { Side effects/drug } \\
\text { interactions and } \\
\text { contradictions }\end{array}$ & References \\
\hline $\begin{array}{l}\text { Opuntia } \\
\text { streptacantha } \\
\text { (Nopal) }\end{array}$ & $\begin{array}{l}\text { Mucopolysaccharide } \\
\text { Fibers, pectin }\end{array}$ & $\begin{array}{l}\text { Slow carbohydrate and } \\
\text { lipid absorption, possibly } \\
\text { increases insulin } \\
\text { sensitivity }\end{array}$ & $\begin{array}{l}\text { Diarrhea, nausea, } \\
\text { abdominal fullness, } \\
\text { increases stool volume, } \\
\text { drug interaction- } \\
\text { improved blood glucose } \\
\text { and insulin with } \\
\text { sulfonylureas (without } \\
\text { hypoglycemia) }\end{array}$ & {$[52,117]$} \\
\hline $\begin{array}{l}\text { Coccinia indica } \\
\text { (ivy gourd) }\end{array}$ & Pectin, triterpenes & $\begin{array}{l}\text { Insulin mimetic, } \\
\text { hypoglycemic activity, } \\
\text { helps lower elevated } \\
\text { levels of } \\
\text { glucose-6-phosphatase } \\
\text { and lactase } \\
\text { dehydrogenase }\end{array}$ & $\begin{array}{l}\text { Allergenic plant } \\
\text { components may cause } \\
\text { hypoglycemia when } \\
\text { combined with } \\
\text { secretagogs }\end{array}$ & {$[52,121]$} \\
\hline
\end{tabular}

indirectly lead to other diseases. Diabetic patients frequently undergo treatment for associated diseases such as hypertension, neuropathy, cardiovascular disease, and so on. While evaluating the effect of CAMs, it is important to understand drugs and drug interactions in depth, and failure to record a patient's present history of CAM use may lead to problems with other prescribed medicines $[38,39]$.

\section{CAM THERAPY: DRAWBACKS AND COMPLICATIONS}

CAM practices pose general risks such as the patient being overloaded with consecutive unsuccessful therapeutic measures owing to false diagnoses, developing life-threatening situations and adverse effects, and hidden costs of treatment $[40,41]$.
Unlike conventional drugs, CAM products, especially herbal medicines and supplements, are complex mixtures of bioactive entities with varying degrees of therapeutic effects. The chemical constitutions of some products vary based on the season, growing conditions, plant part used for extraction, and so on [42, 43]. High variability in levels of ginsenosides in ginseng across different source parameters, viz., ginseng type (batch, preparation, variety, and species), assay technique, and ginsenoside type in turn caused high variability in their efficacy as revealed in a meta-analysis. This is an indication that the reported safety and efficacy data of a particular product may differ greatly when compared to other over-the-counter batches, preparations, varieties, and species of the herb [44]. The complex nature of the products along with poorly regulated manufacturing processes often makes it 
Table 2 Commonly used dietary supplements to treat diabetes

\begin{tabular}{|c|c|c|c|}
\hline Name & $\begin{array}{l}\text { Beneficial effects/hypothesized } \\
\text { mechanism of action }\end{array}$ & $\begin{array}{l}\text { Side effects/potential drug interactions and } \\
\text { contradictions }\end{array}$ & References \\
\hline Chromium & $\begin{array}{l}\text { Lipid-lowering effects, insulin-sensitizing } \\
\text { effect by decreasing tyrosine phosphatase } \\
\text { activity or direct effect on insulin receptor } \\
\text { by increasing tyrosine kinase activity at } \\
\text { the insulin receptor may promote glucose } \\
\text { transport }\end{array}$ & $\begin{array}{l}\text { Renal toxicity and dermatological reactions, } \\
\text { potential hypoglycemia with secretagogs, } \\
\text { steroids may decrease chromium levels, } \\
\text { vitamin C may increase chromium } \\
\text { absorption }\end{array}$ & {$[27,52,117]$} \\
\hline $\begin{array}{l}\text { Omega-3 } \\
\text { fatty } \\
\text { acid/fish } \\
\text { oil }\end{array}$ & $\begin{array}{l}\text { Lowers triglycerides, antiinflammatory, } \\
\text { antiplatelet, hypotensive, slight increase in } \\
\text { blood glucose }\end{array}$ & $\begin{array}{l}\text { High intake might cause bleeding, fish meat } \\
\text { to be eaten with caution because of } \\
\text { contamination with high levels of methyl } \\
\text { mercury; may increase LDL, drug } \\
\text { interactions with anticoagulant and } \\
\text { antihypertension drugs }\end{array}$ & {$[27,28]$} \\
\hline $\begin{array}{l}\text { Alpha-lipoic } \\
\text { acid }\end{array}$ & $\begin{array}{l}\text { Improves insulin resistance and increase } \\
\text { glucose effectiveness }\end{array}$ & $\begin{array}{l}\text { Can affect thyroid function in patients with } \\
\text { thyroid disease, might produce allergic skin } \\
\text { reactions, abdominal pain, nausea, } \\
\text { vomiting, diarrhea, and vertigo }\end{array}$ & {$[28,52,122]$} \\
\hline $\begin{array}{l}\text { Coenzyme } \\
\text { Q10 }\end{array}$ & $\begin{array}{l}\text { Improvement in pain and paraesthesia in } \\
\text { diabetic neuropathy }\end{array}$ & $\begin{array}{l}\text { No effect on blood glucose, additive effects } \\
\text { with antihypertensive drugs }\end{array}$ & {$[21,28,52]$} \\
\hline Magnesium & $\begin{array}{l}\text { Insulin secretagog, essential in glucose } \\
\text { metabolism, prevent diabetic } \\
\text { complications, increased insulin } \\
\text { sensitivity }\end{array}$ & $\begin{array}{l}\text { Diarrhea, abdominal cramping, magnesium } \\
\text { toxicity in individuals with renal failure, } \\
\text { antibiotics, drug interactions with drugs to } \\
\text { prevent osteoporosis, calcium channel } \\
\text { blockers, muscle relaxants, diuretics }\end{array}$ & {$[27,28]$} \\
\hline Zinc & $\begin{array}{l}\text { Improves insulin levels, lipid-lowering } \\
\text { effects, improves weight loss, } \\
\text { metalloenzyme activitor }\end{array}$ & $\begin{array}{l}\text { Nausea, vomiting, reduce absorption of folic } \\
\text { acid, tetracyclines and copper, reduce the } \\
\text { effect of therapies that rely on dopamine } \\
\text { receptor antagonists }\end{array}$ & {$[27,120]$} \\
\hline Vanadium & Insulin mimetic, increase insulin sensitivity & $\begin{array}{l}\text { Prolonged high doses may cause renal toxicity, } \\
\text { gastrointestinal upset }\end{array}$ & {$[28,52]$} \\
\hline
\end{tabular}

difficult to determine possible drug interactions [42].

\section{Complications from Drug Interactions}

Co-administration of herbal medicines or supplements along with conventional therapies is a common practice among patients with diabetes. A possibility of drug interactions with these products exists, which can alter the pharmacokinetics or pharmacodynamics of conventional drugs, resulting in potential side effects $[42,45]$. In case of pharmacokinetic interactions, 
co-administered herbs or supplements may alter the absorption, distribution, metabolism, and/or excretion of conventional drugs. Such interactions can induce and inhibit intestinal and hepatic metabolic enzymes (e.g., CYP enzymes) as well as drug transporters and efflux proteins. For instance, any modulating activity of these herbal remedies on CYP function can greatly influence the bioavailability of conventional drugs [42]. In pharmacodynamic interactions, herbal remedies may interact with the same target molecules leading to synergistic or antagonistic herb-drug interactions. Synergistic effects can cause toxicity and complicate the dosing regimens of medications, whereas antagonistic interactions often lead to decreased efficacy and failure of therapy $[42,46]$.

Owing to the long-term nature of therapies for patients with diabetes, the consequences of these drug interactions can be fatal. Herbs possessing hypoglycemic activity, such as ginseng, garlic, and bitter melon, are all reported to have additive effects in patients taking oral hypoglycemics or insulin [44, 47-49]. In contrast, dietary gums (e.g., gum guar), usually prescribed to overcome postprandial hyperglycemia, were found to reduce the absorption of hypoglycemic agents such as metformin and glibenclamide because of their effect on prolonging gastric retention $[48,50,51]$. A list of some other possible drug interactions reported by earlier investigations or reviews can be found in Tables 1 and 2 .

\section{CHALLENGES TO USING CAM THERAPIES}

\section{Compromised Quality of CAM Products}

Lack of proper adherence to manufacturing, marketing, and storage protocols can lead to deterioration of the product quality, viz., contamination with other substances, intraand inter-product variations, mislabeling of the contents, and so on, thereby leaving us unsure regarding their safety and efficacy $[41,52,53]$. A large percentage of Ayurvedic medicines, both US- and Indian-manufactured, available over the Internet was found to contain lead, mercury, or arsenic, much above their acceptable levels [54], and several studies have reported serious consequences for patients using 'herbal' products that contained 'hidden' active drug compounds or heavy metal contaminants [55-59]. Lead intoxication from the use of Ayurvedic medications has been reported among pregnant women by the Centers for Disease Control and Prevention (CDC), USA [60]. Several Indian herbal medicines were also found to cause lead toxicity in patients with diabetes [61-63]. Some Indian herbal products claiming to be antidiabetic were even reported to be contaminated with hypoglycemic agents such as glibenclamide [64]. Since 2007, the FDA has imposed an import alert on certain Ayurvedic products to prevent such products from entering the USA [65]. Reviewers who undertook a systematic study of Ayurvedic drugs to treat diabetes agree upon a few things. These studies are laden with major methodological limitations such as few randomized trials, underpowered studies, and inappropriate statistical methods, all questioning the credibility of such preparations [32, 66, 67].

Chinese proprietary medicines are no exception, for instance, an antidiabetic preparation marketed as 'wonder pills' contained phenformin, a banned substance [68]. In some cases, toxic herbal constituents became part of the preparation inadvertently. "Chinese herb nephropathy" is a classic example: the herb Stephania tetrandra, supposed to be included in weight-reduction 
pills, was substituted with a nephrotoxic herb, Aristolochia fangchi, causing nephropathy and/ or cancer. Unintended use of Aristolochia fangchi in women attending a slimming clinic in Belgium resulted in one-third of them requiring a renal transplant, and some of the others developed carcinomas [69-71].

\section{Concerns with Other CAM Practices}

Other CAM practices are also not free from side effects. Therapies involving mechanical techniques might cause detrimental effects. Chiropractors, for example, applying controlled force to a spinal joint can cause vertebral arterial dissection after upper spinal manipulation [72]. Acupuncture (stimulating specific points on the body by inserting thin needles through the skin) can cause complications such as pneumothorax [73, 74], cardiac tamponade [75-77], and central nervous system injuries [78]. Serious infectious complications (such as hepatitis, HIV, sub-acute bacterial endocarditis, etc.) can also arise when the practitioners do not follow aseptic techniques $[79,80]$. Discontinuing conventional treatment for acupuncture therapy recently led to the death of a 30-year-old T1DM patient from India [81]. Another peculiar diabetes treatment practiced in Kerala is "sweet therapy," which claims to stimulate the sleeping pancreas to secrete insulin with the intake of glucose-rich foods such as sweet deserts. However, the long-term serious implications of such modalities on the health of the patients are not documented. Mind-body therapies, which involve movements (yoga, tai-chi, etc.) can at best be considered alternative modes of exercise $[82,83]$. They may impart changes in the behavior and psychology of patients, thereby helping them to cope with the disease and increase the overall quality of life [84]. However, neither yoga [85, 86] nor tai-chi [87-89] has been shown to have any significant impact on improving the glycemic status.

\section{Lack of Proper Communication With Health Practitioners}

CAM practitioners usually do not encourage inquiries regarding the constituents of their preparations, and most patients are not very interested in knowing this as they consider such preparations to be 'natural' or 'safe.' Healthcare professionals are mostly unaware of CAM use by their patients and are not consulted prior to their use [90]. All of these factors make it difficult to know whether CAM therapy has played any significant contributory role in the efficacy or failure of a conventional treatment [91].

In its Position Statement on "Unproven Therapies," the ADA raises the concern that most patients do not admit the use of alternative medicine and therefore care providers need to specifically ask their patients about them. The ADA continuously evaluates the effectiveness, potential risk to patients, and so on to characterize the effectiveness of such treatment modalities. They however do not recommend the use of any of these unless their safety and efficacy have been established by current standards [92].

\section{REGULATORY STATUS OF CAM THERAPIES}

\section{Regulations on CAM Products}

Many countries including the USA do not have a comprehensive policy or an authority responsible for CAM and traditional medicine (TM) practices. In the USA, national non-governmental organizations, such as the 
Accreditation Commission for Acupuncture and Oriental Medicine, the American Board of Medical Acupuncture, the Council of Chiropractic Education, and so on, accredit education in some of them, while most other nations do not have these [93]. The Dietary Supplement Health and Education Act (DSHEA 1994) of the US government went on to define the term "dietary supplement," effectively taking out any product containing a vitamin, mineral, herb, or amino acid marketed as a supplement to the normal diet from obtaining USFDA approval for their safety and efficacy, thus leading to their sales even in grocery stores [41, 94].

Only 25 of the WHO's 191 countries have a national policy on TM/CAM, and only 64 countries regulate herbal medicines [95]. In view of this, the WHO published the "Regulatory Situation of Herbal Medicines: a Worldwide Review" with the sole aim of assisting its members in the development of policies and regulations [96]. In India, the Ministry of AYUSH (Ayurveda, Yoga and Naturopathy, Unani, Siddha, and Homoeopathy) was formed in November 2014 by elevation of The Department of AYUSH, with a view to providing focused attention on the development of education and research in these disciplines. The Government of India imposed Good Manufacturing Practices (GMP) under the Drug and Cosmetics Act, 1940, to ensure and enhance the quality of alternative medicines (ASU: Ayurveda, Unani, and Siddha) and also set up a Standards Setting cum Drug Testing Laboratory (Pharmacopoeial Laboratory for Indian Medicine) specifically for these systems of medicine [97]. However, Ayurvedic medicines "prepared in same way as mentioned in ancient Ayurvedic treatises" have been waived from rigorous pharmacological and toxicological studies by rule [98], and products claiming this tend to be widely available to the general public, thereby raising questions regarding their purity, safety, and efficacy. Measures such as these can only hamper the efforts toward control, education, research, and self-regulation.

\section{Regulations on CAM Practitioners}

Another issue of great concern is that CAM practitioners in many countries are not regulated in any manner. There is no system to evaluate the training or expertise of these practitioners [93, 99-101]. This is a serious concern, especially in rural areas where timely access to treatment (government or private) is an issue, as these local practitioners become the primary point of approach and may end up as a hindrance to better treatment options [93, 101]. In many cases, alternative medicine is widely promoted among the public with claims that it is highly effective and supposedly devoid of side effects [98]. 'The Drugs and Magic Remedies (Objectionable Advertisements) Act,' 1954, by the Indian Parliament controls the advertising of drugs in India, restricting advertisements for such 'wonder drugs or remedies' to some extent [102]. Restricting CAM practitioners without any acceptable educational qualifications and adopting standards of practice will be the next appropriate step toward minimizing practice risks [103].

\section{RECOMMENDATIONS FOR PROSPECTIVE CAM USE}

\section{Systematically Controlled Clinical Trials}

Many antidiabetic drugs used in modern medicine have a natural origin [104], and administering them in their natural form may 
not be of much benefit. Metformin, a popular antidiabetic drug, is derived from a traditional antidiabetic plant, Galega officinalis (Goat's Rue or French Lilac) [105], whose active ingredient was found to be galegine or isoamylene guanidine. While guanidine and certain derivatives were found to have toxic effects, the biguanides (two linked guanidine rings) turned out to be beneficial and have been available for therapeutic use since the 1950s. Twenty years later, two of them (phenformin and buformin) were withdrawn because of side effects such as frequent lactic acidosis and increased cardiac mortality. However, a less lipophilic biguanide, metformin, turned out to be safe and was approved for use in the USA in 1995 [106]. Phlorizin, isolated from the bark of apple trees, was found to cause glycosuria [107], but later led to the discovery of better analogs such as dapagliflozin, empagliflozin, and canagliflozin [108]. Exenatide, a glucagon-like peptide-1 (GLP-1) agonist, is a synthetic version of exendin-4, a hormone found in the venom of the Gila monster Heloderma suspectum $[109,110]$. The alpha-glucosidase inhibitor used in T2DM, acarbose, is a pseudo-oligosaccharide isolated from the culture broths of various actinomycetes [111]. With regulated research there is a higher probability that many more natural agents can be used in modern medicine after controlled clinical trials.

Randomized clinical trials of herbal medicine interventions most often underreport the crucial characteristics of the intervention thereby deviating from the standards set by Consolidated Standards of Reporting Trials (CONSORT). CONSORT specifies the necessary information to be included while reporting controlled clinical trials of any intervention including herbal medicines [112, 113]. Experts also recommend that CAM and dietary supplements should be subject to scrutiny similar to conventional medicines by organizations such as the NIH and FDA. Any measure to bypass these may render the healthcare system inefficient, incapable, and dangerous [114, 115].

\section{Proper Patient Counseling}

As more patients with diabetes resort to CAM therapies, modern healthcare practitioners need to be aware of these practices and be prepared to counsel such patients, when needed, about the available options. They should be able to assess as well as present information to the patients regarding the expected risks, side effects, benefits, and choices regarding self-management and the cost to the patient, helping them to make an informed choice [28, 116]. For individuals exploring supplements, FDA documents such as, "Tips for the savvy supplement user," "Tips for older dietary supplement users," "questions and answers on dietary supplements," and so on, might be helpful (accessible at http://www.fda. gov).

\section{CONCLUSIONS}

Age-old systems of alternate medications may be effective for a number of illnesses. However, for a very serious illness like diabetes with multiple long-term complications including, but not limited to, renal and hepatic dysfunction, it is always wiser to follow scientifically studied and proven remedies with known drug interactions and with data on their safety and efficacy in different age groups. CAM practices need to be brought under a regulatory framework and assessed to gain insights into issues concerning their efficacy and safety, 
which will eventually generate faith in these indigenous systems of medicine.

\section{ACKNOWLEDGEMENTS}

No funding or sponsorship was received for the publication of this article. All named authors meet the International Committee of Medical Journal Editors (ICMJE) criteria for authorship for this manuscript, take responsibility for the integrity of the work as a whole, and have given final approval for the version to be published.

Disclosures. J. Kesavadev, B. Saboo, S. Sadikot, A. Kumar Das, S. Joshi, R. Chawla, H. Thacker, A. Shankar, L. Ramachandran, and S. Kalra have nothing to disclose.

Compliance with Ethics Guidelines. This article is based on previously conducted studies and does not involve any new studies of human or animal subjects performed by any of the authors.

Open Access. This article is distributed under the terms of the Creative Commons Attribution-NonCommercial 4.0 International License (http://creativecommons.org/licenses/ by-nc/4.0/), which permits any noncommercial use, distribution, and reproduction in any medium, provided you give appropriate credit to the original author(s) and the source, provide a link to the Creative Commons license, and indicate if changes were made.

\section{REFERENCES}

1. Global report on diabetes. Geneva: World Health Organization; 2016.

2. IDF Diabetes Atlas. Brussels: International Diabetes Federation, 2015.
3. Hirschler B. Diabetes now kills more than HIV, tuberculosis and malaria combined. The Huggington Post, The Times of India; 2015 [cited 2016 11.06.16]; Available from: http://www. huffingtonpost.com/entry/diabetes-deaths_us_5643 e784e4b08cda348777bf?section=india.

4. Life expectancy increased by 5 years since 2000 , but health inequalities persist. Geneva: World Health Organization, Observatory GH; 201619 May 2016 Report No.

5. Mishra S. Does modern medicine increase life-expectancy: quest for the moon rabbit? Indian Heart J. 2016;68(1):19-27.

6. Kesavadev J, Short K, Nair KS. Diabetes in old age: an emerging epidemic. J Assoc Physicians India. 2003;51:1083-94.

7. Ebbell B. The Papyrus Ebers, the Greatest Egyptian Medical Document. Copenhagen; Oxford University Press: London; 1937.

8. Poretsky L. Principles of diabetes mellitus. 2nd ed. Springer; 2010. doi:10.1007/978-0-387-09841-8.

9. Papaspyros NS. The history of diabetes mellitus. 2nd ed. G. Thieme; 1964. p. 213.

10. Sanders LJ. From Thebes to Toronto and the 21st century: an incredible journey. Diabetes Spectr. 2002;15(1):56-60.

11. Ahmed AM. History of diabetes mellitus. Saudi Med J. 2002;23(4):373-8.

12. Deshpande AD, Harris-Hayes $M$, Schootman $M$. Epidemiology of diabetes and diabetes-related complications. Phys Ther. 2008;88(11):1254-64 [Epub 2008/09/20].

13. Forbes JM, Cooper ME. Mechanisms of diabetic complications. Physiol Rev. 2013;93(1):137-88 [Epub 2013/01/11].

14. Cukierman T, Gerstein HC, Williamson JD. Cognitive decline and dementia in diabetessystematic overview of prospective observational studies. Diabetologia. 2005;48(12):2460-9.

15. Nouwen A, Nefs G, Caramlau I, et al. Prevalence of depression in individuals with impaired glucose metabolism or undiagnosed diabetes: a systematic review and meta-analysis of the European Depression in Diabetes (EDID) Research Consortium. Diabetes Care. 2011;34(3):752-62 [Epub 2011/03/02].

16. Adeniyi AF, Adeleye JO, Adeniyi CY. Diabetes, sexual dysfunction and therapeutic exercise: a 20 year review. Curr Diabetes Rev. 2010;6(4):201-6. 
17. Thorve VS, Kshirsagar AD, Vyawahare NS, Joshi VS, Ingale KG, Mohite RJ. Diabetes-induced erectile dysfunction: epidemiology, pathophysiology and management. J Diabetes Complicat. 2011;25(2):129-36.

18. Complementary, Alternative, or Integrative health: what's in a name? USA: National Center for Complementary and Integrative Health; 2016 [updated June 2016 cited 2016 27.09.16]; Available from: https://nccih.nih.gov/health/integrativehealth.

19. Clarke TC, Black LI, Stussman BJ, Barnes PM, Nahin RL. Trends in the use of complementary health approaches among adults: United States, 2002-2012. National Health Stat Rep. 2015;79:1.

20. Black LI, Clarke TC, Barnes PM, Stussman BJ, Nahin RL. Use of complementary health approaches among children aged 4-17 years in the United States: National Health Interview Survey, 2007-2012. National Health Stat Rep. 2015;78:1.

21. Koren R, Lerner A, Tirosh A, et al. The use of complementary and alternative medicine in hospitalized patients with type 2 diabetes mellitus in Israel. J Alternat Complement Med. 2015;21(7):395-400.

22. Astin JA. Why patients use alternative medicine: results of a national study. JAMA. 1998;279(19):1548-53.

23. Barnes PM, Powell-Griner E, McFann K, Nahin RL. Complementary and alternative medicine use among adults: United States, 2002. Semin Integr Med. 2004;2(2):54-71.

24. Naja F, Mousa D, Alameddine M, Shoaib H, Itani L, Mourad Y. Prevalence and correlates of complementary and alternative medicine use among diabetic patients in Beirut, Lebanon: a cross-sectional study. BMC Complement Alternat Med. 2014;14(1):1.

25. Verhoef MJ, Balneaves LG, Boon HS, Vroegindewey A. Reasons for and characteristics associated with complementary and alternative medicine use among adult cancer patients: a systematic review. Integr Cancer Ther. 2005;4(4):274-86.

26. Egede LE, Ye X, Zheng D, Silverstein MD. The prevalence and pattern of complementary and alternative medicine use in individuals with diabetes. Diabetes Care. 2002;25(2):324-9.

27. H-Y Chang, Wallis M, Tiralongo E. Use of complementary and alternative medicine among people living with diabetes: literature review. J Adv Nurs. 2007;58(4):307-19.
28. Birdee GS, Yeh G. Complementary and alternative medicine therapies for diabetes: a clinical review. Clin Diabetes. 2010;28(4):147-55.

29. Chacko E. Culture and therapy: complementary strategies for the treatment of type- 2 diabetes in an urban setting in Kerala, India. Soc Sci Med. 2003;56(5):1087-98.

30. American Diabetes A. Standards of medical care in diabetes-2014. Diabetes Care. 2014;37(Suppl 1):S14-80 [Epub 2013/12/21].

31. Grant SJ, Bensoussan A, Chang D, et al. Chinese herbal medicines for people with impaired glucose tolerance or impaired fasting blood glucose. Cochrane Database Syst Rev. 2009;4(4):CD006690. doi:10.1002/14651858.CD006690.pub2.

32. Sridharan K, Mohan R, Ramaratnam S, Panneerselvam D. Ayurvedic treatments for diabetes mellitus. Cochrane Database Syst Rev. 2011;(12):CD008288. doi:10.1002/14651858. CD008288.pub2.

33. Bauml JM, Chokshi S, Schapira MM, et al. Do attitudes and beliefs regarding complementary and alternative medicine impact its use among patients with cancer? A cross-sectional survey. Cancer. 2015;121(14):2431-8.

34. Kim SH, Shin DW, Nam Y-S, et al. Expected and perceived efficacy of complementary and alternative medicine: a comparison views of patients with cancer and oncologists. Complement Ther Med. 2016;28:29-36.

35. McCarty RL, Weber WJ, Loots B, et al. Complementary and alternative medicine use and quality of life in pediatric diabetes. J Alternat Complement Med. 2010;16(2):165-73.

36. Spinks J, Johnston D, Hollingsworth B. Complementary and alternative medicine (CAM) use and quality of life in people with type 2 diabetes and/or cardiovascular disease. Complement Ther Med. 2014;22(1):107-15.

37. Alfian S, Sukandar H, Arisanti N, Abdulah R. Complementary and alternative medicine use decreases adherence to prescribed medication in diabetes patients. Ann Trop Med Public Health. 2016;9(3):174-9.

38. Guthrie D, Guthrie R. Management of diabetes mellitus: a guide to the pattern approach, 6 edn. New York: Springer Publishing Company, LLC; 2008, p 544.

39. White JR, Jr., Hartman J, Campbell RK. Drug interactions in diabetic patients. The risk of losing 
glycemic control. Postgrad Med. 1993;93(3):131-2, 5-9 [Epub 1993/02/15].

40. Niggemann B, Grüber C. Unconventional and conventional medicine: who should learn from whom? Pediatr Allergy Immunol. 2003;14(3):149-55.

41. Ventola CL. Current issues regarding complementary and alternative medicine (CAM) in the United States: part 2: regulatory and safety concerns and proposed governmental policy changes with respect to dietary supplements. Pharm Ther. 2010;35(9):514.

42. Rehman SU, Choi MS, Choe K, Yoo HH. Interactions between herbs and antidiabetics: an overview of the mechanisms, evidence, importance, and management. Arch Pharm Res. 2015;38(7):1281-98.

43. Shaw D, Graeme L, Pierre D, Elizabeth W, Kelvin C. Pharmacovigilance of herbal medicine. J Ethnopharmacol. 2012;140(3):513-8.

44. Vuksan V, Sievenpiper JL. Herbal remedies in the management of diabetes: lessons learned from the study of ginseng. Nutr Metab Cardiovasc Dis. 2005;15(3):149-60.

45. Marchetti S, Mazzanti R, Beijnen JH, Schellens JH. Concise review: clinical relevance of drug-drug and herb-drug interactions mediated by the $\mathrm{ABC}$ transporter ABCB1 (MDR1, P-glycoprotein). Oncologist. 2007;12(8):927-41.

46. Izzo AA, Ernst E. Interactions between herbal medicines and prescribed drugs. Drugs. 2009;69(13):1777-98.

47. Gardiner P, Phillips R, Shaughnessy AF. Herbal and dietary supplement-drug interactions in patients with chronic illnesses. Am Fam Physician. 2008;77(1):73-8.

48. Izzo AA. Herb-drug interactions: an overview of the clinical evidence. Fundam Clin Pharmacol. 2005;19(1):1-16.

49. Aslam M, Stockley I. Interaction between curry ingredient (karela) and drug (chlorpropamide). Lancet. 1979;313(8116):607.

50. Gin H, Orgerie M, Aubertin J. The influence of guar gum on absorption of metformin from the gut in healthy volunteers. Horm Metab Res. 1989;21(02):81-3.

51. Neugebauer G, Akpan W, Abshagen U. Interaction of guar with glibenclamide and bezafibrate. Beitr Infusionther Klin Ernahr. 1983;12:40.
52. Shane-McWhorter L. Complementary and alternative medicine (CAM) supplement use in people with diabetes: a clinician's guide. Alexandria, Virginia: American Diabetes Association; 2007.

53. Ko RJ. Adulterants in Asian patent medicines. N Engl J Med. 1998;339(12):847.

54. Saper RB, Phillips RS, Sehgal A, et al. Lead, mercury, and arsenic in US-and Indian-manufactured ayurvedic medicines sold via the internet. JAMA. 2008;300(8):915-23.

55. Ernst E. Toxic heavy metals and undeclared drugs in Asian herbal medicines. Trends Pharmacol Sci. 2002;23(3):136-9.

56. Goudie AM, Kaye JM. Contaminated medication precipitating hypoglycaemia. Med J Aust. 2001;175(5):256.

57. Huang WF, Wen KC, Hsiao ML. Adulteration by synthetic therapeutic substances of traditional Chinese medicines in Taiwan. J Clin Pharmacol. 1997;37(4):344-50.

58. Ries CA, Sahud MA. Agranulocytosis caused by Chinese herbal medicines: dangers of medications containing aminopyrine and phenylbutazone. JAMA. 1975;231(4):352-5.

59. Shaw D, Leon C, Kolev S, Murray V. Traditional remedies and food supplements. Drug Saf. $1997 ; 17(5): 342-56$.

60. Lead Poisoning in pregnant women who used ayurvedic medications from India-New York City, 2011-2012. USA: Centers for Disease Control and Prevention; 2012 August 24. Report No.

61. Beigel Y, Ostfeld I, Schoenfeld N. A leading question. N Engl J Med. 1998;339(12):827-30.

62. Keen R, Deacon A, Delves H, Moreton J, Frost P. Indian herbal remedies for diabetes as a cause of lead poisoning. Postgrad Med J. 1994;70(820):113-4.

63. Pontifex AH, Garg AK. Lead poisoning from an Asian Indian folk remedy. Can Med Assoc J. 1985;133(12):1227.

64. Kulambil Padinjakara RN, Ashawesh K, Butt S, Nair R, Patel V. Herbal remedy for diabetes: two case reports. Exp Clin Endocrinol Diabetes. 2009;117(1):3-5 [Epub 2009/01/14].

65. FDA. Use caution with ayurvedic products USA 2008 [cited 2016 23/06]; Available from: http:// www.fda.gov/ForConsumers/ConsumerUpdates/ucm 050798.htm. 
66. Hardy ML, Coulter I, Venuturupalli S, et al. Ayurvedic interventions for diabetes mellitus: a systematic review. Evid Rep Technol Assess (Summ). 2001;(41):2.

67. Elder C. Ayurveda for diabetes mellitus: a review of the biomedical literature. Altern Ther Health Med. $2004 ; 10(1): 44$.

68. Koh H-L, Woo S-O. Chinese proprietary medicine in Singapore: regulatory control of toxic heavy metals and undeclared drugs. Drug Saf. 2000;23(5):351-62.

69. Cosyns J-P, Jadoul M, Squifflet J-P, Wese F-X, de Strihou CVY. Urothelial lesions in Chinese-herb nephropathy. Am J Kidney Dis. 1999;33(6):1011-7.

70. Nortier JL, Martinez M-CM, Schmeiser HH, et al. Urothelial carcinoma associated with the use of a Chinese herb (Aristolochia fangchi). N Engl J Med. 2000;342(23):1686-92.

71. Cosyns J-P. Aristolochic acid and 'Chinese herbs nephropathy'. Drug Saf. 2003;26(1):33-48.

72. Ernst E. Life-threatening complications of spinal manipulation. Stroke. 2001;32(3):809-10.

73. Brettel H. Akupunktur als Todesursache. Munch Med Wochenschr. 1981;123(3):97-8.

74. Mazal DA, King T, Harvey J, Cohen J. Bilateral pneumothorax after acupuncture. $\mathrm{N}$ Engl J Med. 1980;302(24):1365.

75. Cheng TO. Cardiac tamponade following acupuncture. CHEST J. 2000;118(6):1836-7.

76. Kataoka H. Cardiac tamponade caused by penetration of an acupuncture needle into the right ventricle. J Thorac Cardiovasc Surg. 1997;114(4):674-6.

77. Kirchgatterer A, Schwarz CD, Holler E, Punzengruber C, Hartl P, Eber B. Cardiac tamponade following acupuncture. CHEST J. 2000;117(5):1510-1.

78. Peuker ET, White A, Ernst E, Pera F, Filler TJ. Traumatic complications of acupuncture: therapists need to know human anatomy. Arch Fam Med. 1999;8(6):553.

79. Ernst E, White A. Life-threatening adverse reactions after acupuncture? A systematic review. Pain. 1997;71(2):123-6.

80. Rampes H, James R. Complications of acupuncture. Acupunct Med. 1995;13(1):26-33.

81. Greenberg R. Corruption and culture increase diabetes deaths in India. India: The Huffington
Post; 2014. http://www.huffingtonpost.in/entry/ corruption-and-culture-in_b_5897042.

82. Chao Y-FC, Chen S-Y, Lan C, Lai J-S. The cardiorespiratory response and energy expenditure of Tai-Chi-Qui-Gong. Am J Chin Med. 2002;30(04):451-61.

83. Hagins M, Moore W, Rundle A. Does practicing hatha yoga satisfy recommendations for intensity of physical activity which improves and maintains health and cardiovascular fitness? BMC Complement Alternat Med. 2007;7(1):1.

84. Ospina MB, Bond K, Karkhaneh M, et al. Meditation practices for health: state of the research. Rockville, MD: Agency for Healthcare Research and Quality; 2007. https://www.ncbi.nlm.nih.gov/books/ NBK38360/.

85. Aljasir B, Bryson M, Al-shehri B. Yoga practice for the management of type II diabetes mellitus in adults: a systematic review. Evid Based Complement Alternat Med. 2010;7(4):399-408.

86. Innes KE, Vincent HK. The influence of yoga-based programs on risk profiles in adults with type 2 diabetes mellitus: a systematic review. Evid Based Complement Alternat Med. 2007;4(4):469-86 [Epub 2008/01/30].

87. Lam P, Dennis SM, Diamond TH, Zwar N. Improving glycaemic and $\mathrm{BP}$ control in type 2 diabetes: the effectiveness of tai chi. Aust Fam Physician. 2008;37(10):884.

88. Lee M, Pittler M, Kim MS, Ernst E. Tai chi for Type 2 diabetes: a systematic review. Diabet Med. 2008;25(2):240-1.

89. Tsang T, Orr R, Lam P, Comino EJ, Singh MF. Health benefits of Tai Chi for older patients with type 2 diabetes: the "Move It for Diabetes Study"-a randomized controlled trial. Clin Interv Aging. 2007;2(3):429.

90. Tan AC, Mak JC. Complementary and alternative medicine in diabetes (CALMIND) - a prospective study. J Complement Integr Med. 2015;12(1):95-9 [Epub 2015/01/13].

91. Ezuruike UF, Prieto JM. The use of plants in the traditional management of diabetes in Nigeria: pharmacological and toxicological considerations. J Ethnopharmacol. 2014;155(2):857-924.

92. American Diabetes A. Unproven therapies. Diabetes Care. 2004;27(Suppl 1):S135 [Epub 2003/12/25].

93. Debas HT, Laxminarayan R, Straus SE. Complementary and alternative medicine. In: Jamison DT, Breman JG, Measham AR, Alleyne G, 
Claeson M, Evans DB, et al., editors. Disease control priorities in developing countries. 2nd ed. Washington (DC): Oxford University Press, New York; 2006.

94. Berman JD, Straus SE. Implementing a research agenda for complementary and alternative medicine. Annu Rev Med. 2004;55:239-54.

95. WHO. Research guidelines for evaluating the safety and efficacy of herbal medicines: Manila: WHO Regional Office for the Western Pacific; 1993.

96. WHO. Regulatory situation of herbal medicines: a worldwide review. Geneva: World Health Organization; 1998.

97. Singh A. Regulatory and pharmacological bases of ayurvedic formulations. CRC Press; 2016. 268 p. ISBN 9781498750967.

98. Misra A, Gulati S, Luthra A. Alternative medicines for diabetes in India: maximum hype, minimum science. Lancet Diabetes Endocrinol. 2016;4(4):302-3.

99. Mills SY. Regulation in complementary and alternative medicine. Br Med J. 2001;322(7279):158.

100. Bodeker G, Ong CK, Grundy C, Burford G, Shein K. WHO global atlas of traditional, complementary and alternative medicine. Kobe, Japan: WHO Centre for Health Development; 2005.

101. Ries NM, Fisher KJ. Increasing involvement of physicians in complementary and alternative medicine: Considerations of professional regulation and patient safety. Queen's Law J. 2013-2014;39(1):273-300.

102. Drugs and Magic Remedies (Objectionable Advertisements) Act, Stat. 21 (30th April 1954, 1954).

103. Myers SP, Cheras PA. The other side of the coin: safety of complementary and alternative medicine. Med J Aust. 2004;181(4):222-5.

104. Osadebe PO, Odoh EU. Natural products as potential sources of antidiabetic drugs. $\mathrm{Br} \mathrm{J}$ Pharmaceut Res. 2014;4(17):2075.

105. Oubre A, Carlson T, King S, Reaven G. From plant to patient: an ethnomedical approach to the identification of new drugs for the treatment of NIDDM. Diabetologia. 1997;40(5):614-7.

106. Witters LA. The blooming of the French lilac. J Clin Invest. 2001;108(8):1105-7 [Epub 2001/10/17].

107. Ehrenkranz JR, Lewis NG, Kahn CR, Roth J. Phlorizin: a review. Diabetes Metab Res Rev. 2005;21(1):31-8 [Epub 2004/12/30].
108. White JR. Apple trees to sodium glucose co-transporter Inhibitors: a review of SGLT2 inhibition. Clin Diabetes. 2010;28(1):5-10.

109. Eng J, Kleinman W, Singh L, Singh G, Raufman J-P. Isolation and characterization of exendin-4, an exendin-3 analogue, from Heloderma suspectum venom. Further evidence for an exendin receptor on dispersed acini from guinea pig pancreas. J Biol Chem. 1992;267(11):7402-5.

110. Furman BL. The development of Byetta (exenatide) from the venom of the Gila monster as an anti-diabetic agent. Toxicon. 2012;59(4):464-71.

111. Leroux-Stewart J, Rabasa-Lhoret R, Chiasson J-L. $\alpha$-Glucosidase inhibitors. In: DeFronzo RA, Ferrannini E, Zimmet P, Alberti KGMM, editors. International textbook of diabetes mellitus. 4th ed. Chichester, UK: Wiley; 2015. p. 673-85. doi:10. 1002/9781118387658.ch45.

112. Gagnier JJ, Moher D, Boon H, Beyene J, Bombardier C. Randomized controlled trials of herbal interventions underreport important details of the intervention. J Clin Epidemiol. 2011;64(7):760-9.

113. Gagnier JJ, Boon $H$, Rochon $P$, et al. Recommendations for reporting randomized controlled trials of herbal interventions: explanation and elaboration. J Clin Epidemiol. 2006;59(11):1134-49.

114. Cohen K, Cerone P, Ruggiero R. Complementary/ alternative medicine use: responsibilities and implications for pharmacy services. $\mathrm{P}$ AND $\mathrm{T}$. 2002;27(9):440-7.

115. Kwan D, Hirschkorn K, Boon H. US and Canadian pharmacists' attitudes, knowledge, and professional practice behaviors toward dietary supplements: a systematic review. BMC Complement Alternat Med. 2006;6(1):1.

116. MCNZ. Statement on complementary and alternative medicine; 2011. https://www.mcnz. org.nz/assets/News-and-Publications/Statements/ Complementary-and-alternative-medicine.pdf.

117. Geil P, Shane-McWhorter L. Dietary supplements in the management of diabetes: potential risks and benefits. J Am Diet Assoc. 2008; 108(4 Suppl 1):S59-65.

118. DerMarderosian A, Beutler JA. The review of natural products: the most complete source of natural product information. Wolters Kluwer Health; 2010.

119. Shane-McWhorter L. Biological complementary therapies: a focus on botanical products in diabetes. Diabetes Spect. 2001;14(4):199-208. 
120. Smith JD, Clinard VB. Natural products for the management of type 2 diabetes mellitus and comorbid conditions. J Am Pharm Assoc. 2014;54(5):e304-21.

121. Medagama AB, Bandara R. The use of complementary and alternative medicines (CAMs) in the treatment of diabetes mellitus: is continued use safe and effective? Nutr J. 2014;13:102 [Epub 2014/10/22].

122. D'Huyvetter K. Complementary and alternative medicine in diabetes. In: Zazworsky D, Bolin JN, Gaubeca VB, editors. Handbook of diabetes management. Boston, MA: Springer US; 2005. p. 257-71. 